\title{
EXISTIMATIO AS "HUMAN DIGNITY" IN LATE-CLASSICAL ROMAN LAW
}

\author{
Jacob Giltaij*
}

Key words: Dignity; human dignity; Roman law; Roman criminal law; Callistratus

\section{Introduction}

\section{The contested historical origins of the notion of human dignity}

The rise of the notion of "human dignity" as a basis for the modern conception of human rights is currently being hotly debated. As is the case with research into the historical roots of an idea of human rights in general, the origin of the notion is very much tied to its definition, ${ }^{1}$ for how one defines something also determines what its origins are and vice versa. For human dignity, this means distinguishing it from dignity as such, even though the line between the two notions seems arbitrary at best.

1 As shown in the recent volume on Revisiting the Origins of Human Rights (Halme-Tuomisaari \& Slotte (Cambridge) 2015), to which the author has contributed.

* Post-doctoral researcher at the University of Helsinki. This article is written in the context of the ERC-project "Reinventing the Foundations of European Legal Culture" (foundlaw.org, project code: 313100 ). The author wishes to thank Heta Björklund for her kind assistance and editorial prowess. 
In a recent work, Waldron has defined "human dignity" as "levelling-up", indicating the process by which privileges that were previously tied to a certain status or rank now are accorded equally to everyone. ${ }^{2}$ The advantage of this definition is that it is all-encompassing in the sense of taking into account its primary legal, political, theological and philosophical aspects. For instance, "levelling-up" covers both the legal definition of human dignity as it occurs in the constitutions of Germany and South-Africa ${ }^{3}$ as well as its formulation as a value by, for example, Kant. ${ }^{4}$ In this sense the debate between Whitman, who advocates at the very least a relatively law-based definition of the notion of "dignity", 5 and Moyn emphasising its pre-war Catholic roots, ${ }^{6}$ is a paradox if the idea of "levelling-up" is taken as the defining characteristic of human dignity. However, considering the relation between the definition and origin of a historical concept, by identifying human dignity with a general new-found independence from status or rank, is it possible to extend or otherwise argue for a specific historical origin for a notion of human dignity?

As such, the first historical text in which dignitas is used to a certain extent in the sense of "human dignity" is Cicero's theory of the various personae in De officiis 1 105-107. ${ }^{7}$ One of these personae is the persona of reason, which all men share and which sets us apart from animals. ${ }^{8}$ However, the dignity man should embrace according to Cicero is not something that is to be protected against outside interference or violations, but rather consists of living properly in the Stoic sense, that is, in moderation and abstaining from all manner of luxury and overindulgence. ${ }^{9}$ In other words, even though Cicero relates the notions of persona and dignitas to one another, and indicates there is such a thing as a rational persona typical to all human beings, dignitas in Cicero's De officiis is an obligation, not a right. In general, whereas persona in the Roman era gradually developed into a more inclusive notion, ${ }^{10}$ the connotation of dignitas remained one of social status or standing, not the dignity of "man as such". ${ }^{11}$ It was only in the late fifteenth century that dignitas would obtain the meaning of "dignity" in this latter sense. The literature then refers to works by Pico della Mirandola (1486) and Von Pufendorf (1672), still undoubtedly building

2 Waldron 2012: 21, 33-36 and passim.

3 Idem 18-19, 27-28 and 48-49, citing the first chapter of the South-African Constitution (1996) under 1: "The Republic of South Africa is one, sovereign, democratic state founded on the following values: (a) Human dignity, the achievement of equality and the advancement of human rights and freedoms (...)."

4 Idem 2012: 23-26.

5 Whitman 2003: 243-266; Whitman 2004: 1151-1221.

6 Moyn 2014: 19-33; Moyn 2015: 25-64. Also, Waldron 2012: 27-28.

7 Gaudemet 1995: 110; Cancik 2002: 19-39; Cancik 2005: 94-96. See, also, Bloch 1977: 25-37; and for a more general view, Rist 1982: esp 145-152.

8 Cic Off 1 107; Cancik 2005: 96.

9 Cic Off 1 105; Cancik 2005: 95.

10 For example, Pessers 2005: 15-21; van Beers 2009: 53-67; and Stagl 2012: 89-109.

11 On the problem of the various meanings of "dignity", see Waldron 2012: 15-19. 
on Cicero and other ancient sources. ${ }^{12}$ However, the problem remains whether the Romans themselves actually knew and acknowledged "human dignity". The concept is not in any obvious way engrained in the notion of dignitas, whether understood in the sense of social status or moral obligation. This is made all the more uncomfortable by the relation between the notions of persona and dignitas in Cicero: How can the concept of persona have developed into a more inclusive notion, while dignitas was and remained concerned with social status and moral obligation instead of the dignity of "man as such"?

One answer to this question might be that for indicating "human dignity", the Romans actually used a term different from dignitas. There is some reason to suppose this. In the legal writings of the sixteenth century "dignity" for the first time is conceived of - to some degree - as "human dignity" as a right instead of an obligation. The French humanist jurist Donellus (1527-1591) in his Commentarii de iure civili (1589) formulates an early theory of subjective rights one has on his own person, the suum in persona ipsa..$^{13}$ These "personality rights" are the rights to life, body, liberty and dignity. ${ }^{14}$ The remarkable thing about these "personality rights" is their independence from concepts of status or social standing. According to Donellus everyone has these rights regardless of one's position or role in society. As such, their formulation constitutes a breach with the earlier tradition of subjective rights as rights solely related to social class..$^{15}$ Therefore, the catalogue is of major importance for the consecutive development of the notion of subjective rights. Moreover, it appears that Donellus refers to specific Roman legal texts in formulating these "personality rights", which is not that strange considering that the Commentarii de iure civili is basically a systematisation of (received) Roman law. ${ }^{16}$ For instance, violations of these "personality rights" are punished by means of actiones derived from the Roman law of tort or delict, primarily the actio iniuriarum. ${ }^{17}$ They are even seen as a more or less logical corollary to the Roman order of actiones from delict, to the point that Donellus wonders why the Digest did not contain a similar catalogue of personality rights. ${ }^{18}$ Furthermore, in stating these personality rights, Donellus refers to several Roman legal sources directly. For instance, when discussing his "right to freedom" libertas is defined as facere quae velimus, derived from the famous text of Florentinus on libertas as a facultas naturalis. ${ }^{19}$ But with regard to his "right to dignity", Donellus does something quite noteworthy: Instead of stating that a "right

12 Cancik 2005: 95-96.

13 Waider 1961.

14 Idem 60-61; eg in Donellus Commentarii de iure civili (1589) 283 at 229-230 of the 1762 Opera omnia-edition (Waider 1961: 52 n 1); Coing 1982: 253-258.

15 Waider 1961: 61.

16 Idem 54-58.

17 Coing 1982: 254.

18 Giltaij 2011: 26.

19 D 1 5 4; Waider 1961: 60 n 59. See, also, Schrage 1975. 
to dignitas" is protected by the actio iniuriarum as would have made sense based for instance - on D 471012 , he uses the term existimatio and refers to a text by a Roman jurist called Callistratus in D $501351 .^{20}$

\section{Research question}

The reference is telling with regard to the role of personality rights such as dignity in the system Donellus creates. With the specific definition of existimatio as a "position of unimpaired dignitas, which is established by law and custom", Donellus intends to formulate a right to dignity and consequently also to life, body and freedom with a, for lack of a better word, "natural" character, that is rights that every person has regardless of his legal status. But this appears to be only exemplary for the sixteenth century conception of the relation between individual and state based on the individual's "inalienable" personality rights. To be clear, I am using the sixteenthcentury jurist Donellus here as a tool to clarify a particular problem for Roman law, without suggesting whether he is of any value for the content of the Roman legal sources as such. But still, does the conception of Donellus say something about the content and meaning of the Roman legal text itself? Did the Roman jurists intend to formulate a "right to human dignity" relatively independent of social status or circumstance with the term existimatio, as Donellus would centuries later? And what is the exact relation between the terms dignitas and existimatio in the Roman sources?

\section{EXISTIMATIO IN THE LATE REPUBLIC AND EARLY EMPIRE}

If we look at the use of the term "existimatio" in the sources of the late Republic and early Empire, it designates exclusively something along the lines of "standing in society". ${ }^{21}$ This standing, or perhaps rather "image" in modern terminology, ${ }^{22}$ could be violated by rumours and bad press or by an individual's own misconduct. ${ }^{23}$ As such, magistrates ${ }^{24}$ and, later, emperors, ${ }^{25}$ possessed existimatio, which could be violated dictum factumve, as Suetonius states. Various authors point to a close relation between existimatio and infamia as its negative counterpart. ${ }^{26}$ With regard to the Roman legal sources, in his work on the place and role of infamia in Roman law,

20 Waider 1961: 60 n 60; Donellus Commentarii de iure civili (1589) 283 at 229.

21 Yavetz 1974: 39.

22 Ibid.

23 Yavetz 1974: 45; cf Cic Planc 6.

24 For example, Cic Verr 2 60; Yavetz 1974: 38-45.

25 Suet Iul 75; Suet Tib 58; Yavetz 1974: 47.

26 Yavetz 1974: 31 and infra. 
Greenidge devoted a chapter to the meaning of the term existimatio. According to Greenidge, both dignitas and existimatio denote a concept of "civil honour". ${ }^{27}$ This can be seen, for instance, in Cicero Pro Quinctio 15, where Cicero states that when under the Edict of the praetor someone's goods had been seized, also his fama and existimatio are taken away: thus, infamia could to a degree be seen as meaning laesa existimatio, though we cannot be certain whether this truly entailed a legal measure, a form of moral censure, or merely a Ciceronian rhetorical flourish. ${ }^{28}$

In the sense of "civil honour" or "reputation", the term often props up in the legal texts, mainly with regard to the existimatio of tutors ${ }^{29}$ and witnesses. ${ }^{30}$ Furthermore, at some point, the violation of existimatio as well as dignitas came to be punished by means of an actio iniuriarum. Kaser suggests this was done under the Edict rubric ne quid infamandi causa fiat, ${ }^{31}$ due to the connection between existimatio and infamia. ${ }^{32}$ In a concrete sense an individual's existimatio could be violated by a libellus famosus, a verbal or written insult, which was punishable both under iniuria in the Edict as well as the lex Cornelia de iniuriis. ${ }^{33}$ As such, iniuria as a delict sanctioning transgressions against someone else's existimatio could be traced back as far as Labeo or even earlier in the late Republic. ${ }^{34}$ A more direct connection between iniuria and existimatio can be seen in D 471014 and D $471016:^{35}$

D 471014 Ulpianus Libro 56 ad edictum: Et si forte cadaveri defuncti fit iniuria, cui heredes bonorumve possessores exstitimus, iniuriarum nostro nomine habemus actionem: spectat enim ad existimationem nostram, si qua ei fiat iniuria. Idemque et si fama eius, cui heredes exstitimus, lacessatur. (And if perchance the corpse should be contumeliously treated of a deceased to whom we are heirs or recipients of his estate, we have the action for insult in our own right; for it affects our own reputation, if any insult be directed at the corpse. The same applies if the good repute of one to whom we are heirs be damaged. ${ }^{36}$ )

D 471016 Ulpianus Libro 56 ad edictum: Quotiens autem funeri testatoris vel cadaveri fit iniuria, si quidem post aditam hereditatem fiat, dicendum est heredi quodammodo factam (semper enim heredis interest defuncti existimationem purgare) ... (Now whenever there be any affront at the testator's funeral or to his corpse, if it occurs after the inheritance has been accepted, it must be said that in a sense, the insult is to the heir [for it is always the heir's obligation to vindicate the reputation of the deceased] ...)

Idem 19.

Idem 5 n 2; idem 189ff; Brasiello 1937: 549; D 261042.

Brasiello 1937: 552.

Lenel 1956: 323 n 193.

Kaser 1956: 222-223.

See the texts in Kaser 1956: 223 n 18 (iniuria) and n 19 (lex Cornelia de iniuriis).

Made explicit in various texts of post-classical jurists: Brasiello 1937: 547; Hagemann 1998: 137 138.

35 Kaser 1956: 231 n 58.

36 Translations from the Digest are by Watson. 
The heirs to an estate may bring an actio iniuriarum under their own name when the body of the deceased has been violated, because this violation both concerns the existimatio of the deceased and the existimatio of the heirs. This concept of existimatio is close to the one argued by Greenidge, more "civil honour" than "human dignity". But seeing the connection between existimatio and infamia, it goes to wonder whether a violation of existimatio is implied in other parts of the Edict rubric on iniuria or even with regard to other actiones famosae, carrying the punitive measure of infamia.$^{37}$ However, according to Kaser, existimatio in the context of the Edict is not used by the jurists in a technical legal sense. ${ }^{38}$ The same goes for the notion of existimatio in D 5013 5, the text referred to by Donellus some 1300 years later in his formulation of a personal right to dignity. ${ }^{39}$

\section{D 50135 AND THE LIBRI DE COGNITIONIBUS}

The late-classical jurist Callistratus ${ }^{40}$ writes his text in the context of a larger manual on the cognitio-procedure. ${ }^{41}$ The text primarily regards a loose subdivision of the genera of the procedure based on the punishment the trial would lead to:

D 5013 5pr Callistratus Libro primo de cognitionibus: Cognitionum numerus cum ex variis causis descendat, in genera dividi facile non potest, nisi summatim dividatur. Numerus ergo cognitionum in quattuor fere genera dividi potest: aut enim de honoribus sive muneribus gerendis agitatur, aut de re pecuniaria disceptatur, aut de existimatione alicuius cognoscitur, aut de capitali crimine quaeritur. (The number of judicial examinations, since it arises from various causes, cannot easily be divided into categories, unless this is done schematically. But the number of judicial examinations can perhaps be divided into four categories; for it is either a question of the undertaking of offices and munera, or of property, or of someone's status, or of a capital offence.)

In the principium, the cognitio-trial is subdivided into four genera: Regarding the administration of offices, regarding pecuniary matters, regarding existimatio and concerning capital offences. ${ }^{42}$ Although the need for these kinds of manuals is easy to see in the context of a cognitio-trial after the degradation of the legal framework that existed in the late Republic and early Empire, the exact nature of the separation between trials regarding pecuniary matters, existimatio and capital offences remains summatim, as Callistratus himself describes it. For instance, following Cicero Pro Quinctio 15, a judgment based on the Edict could concern both a pecuniary matter as well as the existimatio of the condemned, even though Callistratus puts it under

40 For biographical information on the jurist, see Bonini 1964: 11-21; Kunkel 1967: 235 no 61.

41 Lenel 1887-1889: vol 1 cols 80-94; Kaser 1956: 264-265; Bonini 1964: $29 \mathrm{ff}$.

42 Brasiello 1937: 554-558; Bonini 1964: 32ff; Liebs 1966: 263. 
the heading of trial regarding existimatio in D 501353 . Also, the relation between infamia in the Edict of the praetor and infamia as the result of committing a capital offence in any of the stages of development of Roman law hardly follows the neat distinction suggested by Callistratus ${ }^{43}$ In any case, the jurist goes on to treat the cognitio-trial regarding someone's existimatio:

D 501351 Callistratus Libro primo de cognitionibus: Existimatio est dignitatis inlaesae status, legibus ac moribus comprobatus, qui ex delicto nostro auctoritate legum aut minuitur aut consumitur. (Status is a position of unimpaired standing, which is established by law and custom and under the authority of the laws may be reduced or removed by our delict.)

Thus we come to the definition of existimatio also referred to by Donellus in the construction of his right to human dignity in the sixteenth century. Existimatio is, in the Watson-translation, primarily defined as "a position of unimpaired standing, which is established by law and custom". On the basis of this text, Greenidge draws a parallel between existimatio and caput in Roman law, where existimatio has a moral as well as a legal dimension. ${ }^{44}$ However, as Kaser points out, the comparison is somewhat flawed because the diminution of caput or capitis deminutio is a proper legally subscribed sanction, contrary to infamia as it seems to be referred to in the latter part of the text. ${ }^{45}$ As such, infamia as laesa existimatio has more in common with the Republican nota censoria, a punitive administrative measure issued by the censor on moral grounds, ${ }^{46}$ only in this case applied by the magistrates in the cognitio-trial. Yet, the scope of this laesa existimatio is much greater than a mere moral sanction or even a moral punitive measure with legal consequences such as infamia. This becomes apparent from D 50135 2-3:

Callistratus Libro primo de cognitionibus: (2) Minuitur existimatio, quotiens manente libertate circa statum dignitatis poena plectimur: sicuti cum relegatur quis vel cum ordine movetur vel cum prohibetur honoribus publicis fungi vel cum plebeius fustibus caeditur vel in opus publicum datur vel cum in eam causam quis incidit, quae edicto perpetuo infamiae causa enumeratur. (3) Consumitur vero, quotiens magna capitis minutio intervenit, id est cum libertas adimitur: veluti cum aqua et igni interdicitur, quae in persona deportatorum evenit, vel cum plebeius in opus metalli vel in metallum datur: nihil enim refert, nec diversa poena est operis et metalli, nisi quod refugae operis non morte, sed poena metalli subiciuntur. (2) Status is reduced if we are assigned a penalty which affects our standing, although liberty remains, as, for instance, if someone is banished or removed from the ordo or debarred from holding public office or if a plebeian is beaten with rods or assigned to forced labor or if anyone falls under any heading which is listed in the perpetual edict as bringing infamy. (3) Status is removed if magna capitis deminutio occurs, that is, if deprivation of liberty occurs, as, for instance, if someone is forbidden fire and water, which occurs when he is deported or

43 Mommsen 1899: 995 n 2; Greenidge 1894: 154-170; Kaser 1956: 254-263.

44 Greenidge 1894: 5-8.

45 Kaser 1956: $266 \mathrm{n} 22$.

46 Greenidge 1894: 41-112, esp 60-74; Giltaij 2011: 55-61. 
if a plebeian is assigned mine work or to a mine; for it makes no difference, nor is there any distinction between a public work and a mine, except that those who escape from a public work are punished not by death, but by assignment to a mine.)

Based on the text, the diminution of existimatio in a cognitio-trial is synonymous with a panoply of penalties, such as exile, exclusion from certain magistracies, whipping, forced labour and praetorian infamia. Moreover, the complete loss of existimatio as well as libertas occurs when someone is sentenced by aqua et ignis interdictio to deportation or a plebeian to forced labour in the mines. Even though the character of the laesa existimatio and capitis deminutio may differ, it is telling that Callistratus calls the latter condition a capitis deminutio magna, by loss of factual liberty or possibly even the status libertatis encompassing both the legal capitis deminutio media and maxima ${ }^{47}$ When existimatio in the late Republic and the early Empire meant "civil honour", it is clear that the notion of existimatio that Callistratus refers to in this text, namely the existimatio diminished or even lost by these sentences, goes far beyond "reputation". Looking at the penalties, these range from losing civic privileges to corporal punishment and that which could easily be seen as punishments akin to the death penalty. Then the question is, what does this text say about the "positive" implications of the notion of existimatio in Roman law?

Kaser states that existimatio in this text is not simply an individual condition of being legally untouched by infamia, but rather human dignity in a general sense, transgressed upon by the catalogue of penalties. ${ }^{48}$ If this is the case, existimatio would mean human dignity on a very basic level, entailing the integrity of life and limb as well as reputation, and relatively independent from rank compared to the notion of dignitas, seeing plebeians and possibly even slaves have an existimatio that is affected by the punishment. ${ }^{49}$ Callistratus confirms this reading when he revisits the penalties regarding existimatio in the sixth book of his Libri de cognitionibus dealing with capital punishment: ${ }^{50}$

D 819281 Callistratus Libro sexto de cognitionibus: Ceterae poenae ad existimationem, non ad capitis periculum pertinent, veluti relegatio ad tempus, vel in perpetuum, vel in insulam, vel cum in opus quis publicum datur, vel cum fustium ictu subicitur. (The remaining

47 Kaser 1956: 265; cf Gai Inst 1160 and 161.

48 Kaser 1956: 266: "Für unserer Zweck ist vielmehr nur wesentlich daß die existimatio, von der hier die Rede ist, nicht einfach die juristische Unbescholtenheit im Gegensatz zum Infamie ist, sondern in einem viel allgemeiner Sinn der Zustand unverletzten Menschenwürde, der durch alle aufgezählten Strafen von der Relegation bis zur Bergwerkstrafe geschmälert wird"; see, also, Bonini 1964: 37. Like Waldron 2012: 48-50, I use "human dignity" here in a very legal sense, meaning as a form of protection against degrading treatment as it occurs in various international treaties and constitutional documents nowadays.

49 This depends on reading D $4919282-5$ as a single text, all dealing with punishments affecting existimatio. Slaves are referred to in D 491928 4. Lenel (1887-1889) reads them as subsequent: vol 1 cols 91-92.

50 Lenel 1887-1889: vol 1 cols 91-94, col 91 no 42; Mommsen 1899: 908-909; Bonini 1964: 86-90. 
punishments relate to a person's reputation, not to the risk of his caput, such as relegation, for a period or permanently, or to an island, or when someone is handed over to forced labor, or punished by beating with rods [tr Watson cs]).

Apart from D 50135 and D 4819 28, the function and content of the concept of existimatio in Callistratus remains rather unclear. Only one other text from the libri de cognitionibus appears to concern the loss of existimatio as a penalty specifically: ${ }^{51}$

D 481926 Callistratus Libro primo de cognitionibus: Crimen vel poena paterna nullam maculam filio infligere potest: namque unusquisque ex suo admisso sorti subicitur nec alieni criminis successor constituitur, idque divi fratres Hierapolitanis rescripserunt. (The crime or punishment of the father cannot inflict any stain on the son; for each individual suffers his fate for his own crime, nor is he made the successor to the offence of another; as the deified brothers wrote in a rescript to the citizens of Hierapolis [tr Watson cs]).

However, contrary to what Bonini states ${ }^{52}$ the text seems to regard the trials regarding munera rather than the trials concerning existimatio, both to be found in the first book of the Libri de cognitionibus. ${ }^{53}$ The "stain" mentioned in the text would have been important as an impairment - whether in the guise of infamia or not - for the son to take office, and thus Callistratus and the Divi Fratres before him made it clear that a son does not inherit the crime his father committed.$^{54}$ In any case, even though the text is taken from the first book, it does not shed a great deal of light on the nature and function of the trials regarding the existimatio of the suspect.

\section{THE NOTION OF EXISTIMATIO IN THE LATE- CLASSICAL ROMAN LEGAL SOURCES}

\section{The scope of existimatio}

There are, however, plenty of examples of the genus of the trials regarding existimatio in later legal texts, primarily imperial constitutions..$^{55}$ According to Brasiello, lateclassical jurists such as Callistratus had aimed to create a new genre of trial and punishment within the cognitio-procedure. These poenae or iudicia existimationis were to stand between pecuniary and capital punishment, and regarded any (cognitio-)trial in which the moral integrity of the accused was in question. ${ }^{56}$ Ulpian, for example, uses the notion in the seventh book of his De officio proconsulis with regard to rescripts of Trajan to his provincial governors: ${ }^{57}$

51 Lenel 1887-1889: vol 1 cols 84-85 nos 10-11; Von Lübtow 1948: 512-513; Bonini 1964: 51-52.

52 Bonini 1964: 52.

53 Lenel 1887-1889: vol 1 cols 81-85.

54 Greenidge 1894: 209-213.

55 Brasiello 1937: 561.

56 Idem 550; Cic $Q$ Rosc 6 16. See, also, Yavetz 1974: 37-40.

57 Coenraad 2000: 134-141; Nogrady 2006: 112-125. 
D 4819 5pr Ulpianus Libro septimo de officio proconsulis: Absentem in criminibus damnari non debere divus Traianus Iulio Frontoni rescripsit. Sed nec de suspicionibus debere aliquem damnari divus Traianus Adsidio Severo rescripsit: satius enim esse impunitum relinqui facinus nocentis quam innocentem damnari. Adversus contumaces vero, qui neque denuntiationibus neque edictis praesidum obtemperassent, etiam absentes pronuntiari oportet secundum morem privatorum iudiciorum. Potest quis defendere haec non esse contraria. Quid igitur est? Melius statuetur in absentes pecuniarias quidem poenas vel eas, quae existimationem contingunt, si saepius admoniti per contumaciam desint, statui posse et usque ad relegationem procedi: verum si quid gravius irrogandum fuisset, puta in metallum vel capitis poenam, non esse absentibus irrogandam. (The deified Trajan wrote in a rescript to Julius Fronto that in criminal cases a person should not be condemned in his absence. He also wrote in a rescript to Adsidius Severus that neither ought a person to be condemned on suspicion; for it was preferable that the crime of a guilty man should go unpunished than an innocent man be condemned. However, judgment ought to be pronounced against contumacious persons who fail to comply with the summonses or edicts of the governors, even in their absence, after the manner of private actions. It is possible to maintain that these principles are not contradictory; what, then, is the answer? It will be better to lay down that penalties involving money or affecting a person's reputation can be imposed on absent persons if, after frequent warnings, they fail [to appear] through contumacy, and this may go as far as relegation; but if there is any heavier penalty to be imposed, let us say condemnation to the mines or capital punishment, it must not be imposed on the absent [tr Watson cs]).

The subdivision made by Callistratus in trials regarding pecuniary matters, trials concerning existimatio and trials regarding capital offences is quite clearly present in this text. Pecuniary penalties or punishment regarding the existimatio of a suspect can be imposed even when the party is absent, while the presence of the accused is required when harsher measures are in order. It is interesting to note that while Callistratus classifies "hard labour" as a loss of existimatio, to Ulpian metallum is more akin to capital punishment. ${ }^{58}$ Both jurists do, however, state relegation as a penalty affecting existimatio: Since the Libri de cognitionibus were probably composed around AD $197^{59}$ and De officio proconsulis at least after AD 212, ${ }^{60}$ it might be fair to say that Ulpian took his subdivision and concept of existimatio for the larger part from Callistratus. ${ }^{61}$ However, Liebs suggests a precursor in Venuleius Saturninus De iudiciis publicis. ${ }^{62}$ In any case, seeing that Callistratus devotes separate books to the discussion of the various kinds of trial, the seventh book of Ulpian's $D e$ officio proconsulis may also have contained texts relevant specifically to the notion of existimatio.

Most of the texts in book 7 of De officio proconsulis appear to concern punishments and matters closely related to the penalty, ${ }^{63}$ and the persona and

58 Coenraad 2000: 138-139 (meaning the death penalty).

59 Bonini 1964: 15; Liebs 1966: 257.

60 See, eg, Honoré 2002: 184.

61 Bonini 1964: 29-31; Liebs 1966: 262.

62 Liebs 1966: 262.

63 Lenel 1887-1889: vol 2 col 973 no 2180, col 977 no 2201; Nogrady 2006: 40-41. 
dignitas of the accused are referred to explicitly in several texts, for instance in $\mathrm{D} 48$ $137(6) 2$ regarding the punishment for the crimen de peculatu ${ }^{64}$ However, the term "existimatio" is not used in any of the other texts taken from the seventh book of De officio proconsulis. When Ulpian does use the term once again, he does so in his commentary on the lex Iulia et Papia: ${ }^{65}$

\begin{abstract}
D 50161311 Ulpianus Libro tertio ad legem Iuliam et Papiam: Inter "multam" autem et "poenam" multum interest, cum poena generale sit nomen omnium delictorum coercitio, multa specialis peccati, cuius animadversio hodie pecuniaria est: poena autem non tantum pecuniaria, verum capitis et existimationis irrogari solet. Et multa quidem ex arbitrio eius venit, qui multam dicit: poena non irrogatur, nisi quae quaque lege vel quo alio iure specialiter huic delicto imposita est: quin immo multa ibi dicitur, ubi specialis poena non est imposita. Item multam is dicere potest, cui iudicatio data est: magistratus solos et praesides provinciarum posse multam dicere mandatis permissum est. Poenam autem unusquisque inrogare potest, cui huius criminis sive delicti exsecutio competit. (But there is a considerable difference between a "fine" and a "penalty", since a penalty is a general name for the punishment of all delicts, a fine is tied to a misdemeanor, whose punishment today is in monetary form. But a penalty is not only of monetary form, but may be capital or involve status. And, indeed, a fine arises from the judgment of a man who pronounces the fine. A penalty is not imposed, except that which is laid down especially for the delict in question by each law or some other provision. So a fine is pronounced in cases where a special penalty is not laid down. Likewise, a man who possesses jurisdiction can pronounce fines. But anyone to whom the prosecution of the offence or delict in question falls can impose a penalty.)
\end{abstract}

Callistratus's subdivision can be read in this text as well, although it is made subordinate to the difference between a multa and a poena, the former being a pecuniary penalty, the latter also affecting the caput and existimatio of the accused. The text appears to have a more theoretical character: According to Ulpian, a poena regarding the existimatio of the accused can only be imposed if this is prescribed by a law or some other authority, and furthermore, only those who possess iurisdictio may inflict such a penalty. As such, it appears penalties regarding existimatio were reserved for rather specific transgressions, even though as with D 50135 and D 48 195 it remains unclear which transgressions Callistratus and Ulpian have in mind exactly. It stands to reason these are the transgressions to which previously infamia as a punitive measure had been appended. Important in listing these transgressions is emphasising that at least from the third century onwards, this measure could be appended somewhat equally to transgressions both in public and private criminal law. ${ }^{66}$ This may have had something to do with the integration of various types of procedure into the cognitio-trial, but does not necessarily have to follow from it. ${ }^{67}$

64 Nogrady 2006: 126-136, esp 133-134.

65 Also, Modestinus in D 5016 103; Mommsen 1899: 907.

66 Macer in D 48 1 7; Mommsen 1899: 996-998; Kaser 1956: 269.

67 Mommsen 1899: 997; Liebs 1966: 258-263. 


\section{The possible origin of existimatio}

Kaser provides a list of these transgressions, ${ }^{68}$ among which violations of tutela, fiducia and societas ${ }^{69}$ as well as iniuria ${ }^{70}$ due to an earlier connection with the term existimatio catches the eye immediately. To this list we may add other various other non-capital crimina as Brasiello does. ${ }^{71}$ However, even though Callistratus and Ulpian may have had specific transgressions in mind, from the sources no direct connection stemming from the use of infamia as a punitive measure between the iudicia existimationis and specific transgressions either in the Libri de cognitionibus ${ }^{72}$ or book 7 of De officio proconsulis can be argued decisively. For instance, in the seventh book of De officio proconsulis, the crimen laesio maiestatis and the crimen de sicariis et veneficiis are stated. To these crimes, infamia was not in any obvious way attached, and should be seen on the whole as "capital" crimes. ${ }^{73}$ In general, the problem in this regard is the measure in which infamia and existimatio in their "technical" meaning in the context of these transgressions in the cognitio-trial are related to "non-technical" infamia and existimatio as they occur in D 50135 and its related texts. ${ }^{74}$ With regard to the "non-technical" concept of existimatio, Kaser refers to an origin in rhetoric. ${ }^{75}$ Perhaps we can see an early example of this rhetorical use of the term in Papinian: ${ }^{76}$

D 28715 Papinianus Libro sexto decimo quaestionum: Filius, qui fuit in potestate, sub condicione scriptus heres, quam senatus aut princeps improbant, testamentum infirmet patris, ac si condicio non esset in eius potestate: nam quae facta laedunt pietatem existimationem verecundiam nostram et, ut generaliter dixerim, contra bonos mores fiunt, nec facere nos posse credendum est. (A son who was in parental power, appointed heir under a condition which the senate or the emperor disapproves, may upset his father's will, as if the condition were one not in his power [to fulfill]; for any acts which offend our sense of duty, our reputation, or our sense of shame, and, if I might speak generally, which are done against sound morals, it is not to be accepted that we are even able to do.)

But apart from this text, the origin of the term existimatio as it is used by Callistratus in D 50135 is not clear. Kaser refers mainly to Cicero Pro Caecina 100, ${ }^{77}$ but the text does not contain the term existimatio as such. Moreover, we have already

68 Kaser 1956: 267 n 225.

69 Cicero, Pro Q Roscio Comoedo 616.

70 D $471041 / 6$.

71 Brasiello 1937: 547-561; Mommsen 1899: 996-998.

72 Lenel 1887-1889: vol 1 cols 90-91; Bonini 1964: 141-149.

73 Lenel 1887-1889: vol 2 cols 975-977.

74 Kaser 1956: 231 n 58.

75 Idem 267.

76 Babusiaux 2011: 236-238. See, also, Marcus Aurelius in Callistratus Libro quinto de cognitionibus D 48 7 7; Bonini 1964: 125-128.

77 Kaser 1956: 267. 
seen that existimatio in the sources of the late Republic and early Empire means "reputation" or "civil honour" exclusively. This appears to be no different in the rhetorical treatises. ${ }^{78}$ Therefore, there does not seem to be a logical precursor to the concept of existimatio as it is stated by Callistratus in the Latin texts.

It should, however, not be forgotten there is some reason to suppose an oriental, possibly Greek, background to Callistratus's life and work. ${ }^{79}$ Apart from quoting several rescripts in Greek to cities in the eastern provinces ${ }^{80}$ in his Libri de cognitionibus Callistratus provides a substantial reference to the Greek text of Plato's Politeia, the only Plato-reference in the whole of the Digest. ${ }^{81}$ Even though this does not prove that Callistratus lived and worked in a predominantly Greek-speaking part of the Empire, it does show a rather profound interest in Greek culture. Moreover, it should be noted at this point that the penal theories of Plato had somewhat of a "Nachleben" in the second century AD Roman sources, for instance in a large discussion in Aulus Gellius. ${ }^{82}$ As such, Callistratus could have constructed his concept of existimatio and the poenae existimationis from Greek or oriental legal examples or even Greek philosophical texts. According to Yavetz, the Greek equivalents of

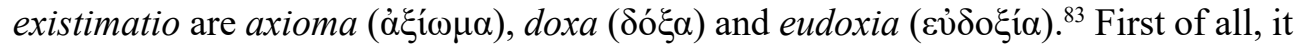
is interesting to see all three Greek terms as they are used mainly in a philosophical context have the same double meaning of "opinion" and "reputation" existimatio

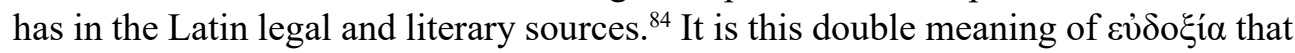
Socrates plays with in Plato's Menoon ${ }^{85}$ This platonic usage of $\delta o ́ \xi \alpha / \varepsilon v j \delta o \xi i ́ \alpha$ has been adopted by the Stoics in particular. ${ }^{86}$ In the Stoic sources, $\delta$ ó $\xi \alpha / \varepsilon v ̉ \delta o \xi i \alpha$ carries an ethical connotation as a (preferred) $\dot{\alpha} \delta$ íxpopov or indifferens, those goods which are preferable to have but are not necessary to lead a "life according to nature". ${ }^{87}$

In the sense of an $\dot{\alpha} \delta t^{\alpha} \varphi \rho \rho o v$, existimatio appears to occur in the Latin sources as well, for example in Seneca and later in Aulus Gellius. ${ }^{88}$ Seeing then that various authors have argued a relation between the development of the notion of persona in Roman law and Stoic ethical doctrine, it is interesting to assess whether Callistratus

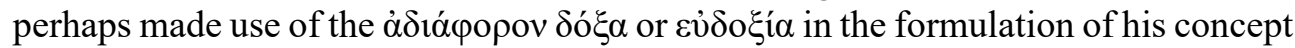
of existimatio. From the era of Callistratus, that is to say the second century AD,

78 For example, Cic De or 2184 and Sen Controv 27.

79 Bonini 1964: 12-13; Kunkel 1967: 235.

80 D 506 5; D 83 16; Bonini 1964: 70, 153-167.

81 D 50112 from the Politeia; Lenel 1887-1889: vol 1 col 86 no 21; Bonini 1964: 75-76.

82 Gell NA 20 1; Robinson 2007: 179-195.

83 Yavetz 1974: $52 \mathrm{n} 48$.

84 For example, regarding d่ $\xi i ́ \omega \mu \alpha$ SVF 25 no 13, SVF 260 no 186 and SVF 261 no 188; and Rist 1982: 145.

85 Pl Menoon 99a-99b; Weiss 2001: 164.

86 Long \& Sedley 1987b: 349-351.

87 Reesor 1951: 102-110; Pohlenz 1992: 120-123; Rist 1969: 102-105; Long 1974: 192-199; Long \& Sedley 1987a: 354-359.

88 Sen Ep 95 58; Gell NA 181. 
there are two texts from the Stoicorum Veterum Fragmenta dealing with $\delta$ o $\xi \alpha$ as an $\dot{\alpha} \delta 1 \alpha \dot{\alpha} \varphi \rho \rho o v$, which are both from neoplatonic sources hostile to Stoicism. In De stoicorum repugnantis, Plutarch refers to a remark made by Chrysippus, who may have argued for rhetoricians to pretend for political purposes matters such as wealth or $\delta o ́ \xi \alpha$ are proper in the ethical sense. ${ }^{89}$ Also, Sextus Empiricus in his diatribe Adversus mathematicos gives a rather detailed description of the Stoic doctrine of "preferred" indifferents, among which $\delta$ ó $\xi \alpha$ is mentioned..$^{90}$ Yet, the depth and complexity of Callistratus's conception of existimatio as something that can be violated by a penalty handed out by a magistrate is carried by neither of these texts. Moreover, it is not clear whether $\delta$ ó $\xi \alpha$ or existimatio in the ethical doctrine of the Stoics in general could even be seen as something as fundamental as "human dignity", and intends to state more than reputation or "civil honour". On the other hand, notwithstanding their character and role as "indifferents", the Stoic $\alpha \delta$ ió $\varphi \rho \rho \alpha$ also entail health and strength, matters pertaining to the condition of the human being as such.

\section{CONCLUSION}

So, where does the notion of existimatio as "human dignity" as formulated by Callistratus come from? Firstly, the possibility must be stated that Callistratus himself invented this notion and its procedural consequences in the Roman law of his time, and that this notion was taken over and adapted by the jurists Ulpian and Modestinus. This establishes Callistratus, of whom we know comparatively little, as a highly influential and original thinker, even though neither Ulpian nor Modestinus quotes him directly in any text. Since there is no logical precursor to Callistratus's notion of existimatio, at least not in an obvious way present in the Roman legal or Greek philosophical sources, or, to my knowledge, Greek law or Christian theology, we have to assume he himself constructed this notion and the procedure surrounding it. Then, the remarkable conclusion to this article must be that, considering the Donellus-quotation, one of the first precursors of the idea of "human dignity" as a right is an otherwise almost completely unknown jurist from the second century $\mathrm{AD}$, whose work we only know now inasmuch as we do due to historical circumstance upon historical accident.

There is, however, another possibility. Crifò has shown a prevalence of neoplatonic ideas in the works of Ulpian due to the influence of the circle of Julia Domna, the wife of the emperor Septimius Severus. ${ }^{91}$ Instead of Ulpian taking his cue from Callistratus, both Callistratus and Ulpian could have constructed the notion of existimatio as "human dignity" from the same source. Seeing the neo-platonic influence on Ulpian and the Plato-citation in Callistratus, this might very well be

89 Reesor 1951: 104; Plut De stoicorum repugnantis 1034b (SVF 3175 no 698).

90 Sext Emp Math 1159 (SVF 329 no 122).

91 Crifò 1976: 734-736ff; also, Honoré 2002: 80-82. 
a source with a (neo-)platonic character. The possible character of existimatio as a Stoic $\dot{\alpha} \delta \dot{\alpha}^{\prime} \varphi \rho \rho o v$ is then explained through the integration of Stoic notions in platonic thought in the late second century AD. ${ }^{92}$ In other words, the notion of existimatio as stated by Callistratus could be a combination or integration of the platonic theories of state and punishment and a Stoic conception of dignity or even "human dignity" as an $\dot{\alpha} \delta \dot{\alpha}^{\prime} \varphi \rho_{0}$ ov. For this, to my knowledge, a singular source in which these elements are combined before Callistratus is lacking, but all the elements separately are certainly present in one place, for instance in Aulus Gellius.

Finally, even without any absolute knowledge on the origin of the notion of existimatio in Callistratus, the context and the usage in and of itself have some fascinating implications. The construction of "human dignity" as something the Roman "state" may only violate by means of a punishment handed out in a trial, almost as if it were a right in the modern sense, is something we would expect in a seventeenth or eighteenth century political treatise, not in the works of a second century AD resident of the Roman empire. So how does the notion of existimatio in the late-classical legal sources fit into the modern debate on the origins of human dignity? With Waldron, for existimatio to qualify as a type of human dignity, we need to ask ourselves if a "levelling-up" has taken place, in the sense of privileges being accorded more equally than before the formulation of the notion. Although I would say there are definite similarities between existimatio as employed by Callistratus and "human dignity" as it occurs in the modern constitutions of Germany and SouthAfrica, particularly in its practical application in criminal law, we lack the historical detail to determine this with any kind of certainty.

The problem here is mainly the role existimatio has in the work of Callistratus, namely as a systematising notion rather than an ethical one. Still, even taking this purpose into account, the relative independency of existimatio from notions of rank and status is a noteworthy aspect of this definition, specifically compared to dignitas as it occurs in the Roman legal sources. Moreover, the conclusion must still be that the notion of existimatio as formulated by Callistratus speaks for the presence of ideas of state and individual already among the Roman jurists, if only to the point of there being a divide between the two. Whether or not this was a part of a larger theory on the persona in Roman law or whether or not this persona was comprised of Stoic àdóx $\varphi \rho \rho \alpha$, Callistratus's conception of existimatio tells us something about the way in which Roman jurists thought about what makes a person a person. For several Roman jurists, dignity consists of more than reputation, and in a way is more basic than that: It is also the absence of pain, suffering, humiliation and compulsion, and as such an equal part of every person, whatever his position in society might be.

92 In Plotinus and Porphyry: Wallis 1972: 82-84; Smith 1987: 762; Dombrovski 1987: 776-778 etc. 


\section{ABSTRACT}

Even though there are similarities between the two notions, in antiquity the term dignitas generally speaking does not have the same meaning as our modern idea of "human dignity". However, there is a possibility that for "human dignity" some Roman jurists actually used a term different from dignitas, namely existimatio. This article examines whether the term existimatio in the work of one Roman jurist in particular may be seen as akin to our modern conception of "human dignity", and, if so, what the scope and origin of existimatio in the late-classical Roman legal sources were.

\section{BIBLIOGRAPHY}

Babusiaux, U (2011) Papinians Quaestiones. Zur rhetorischen Methode eines spätklassischen Juristen (München)

Bloch, E (1977) Naturrecht und Menschliche Würde (Frankfurt am Main)

Bonini, R (1964) I "Libri de Cognitionibus" di Callistrato. Ricerche Sull'elaborazione Giusprudenziale della "Cognitio Extra Ordinem” (Milano)

Brasiello, U (1937) La Repressione Penale in Diritto Romano (Napoli)

Cancik, H (2002) “'Dignity of man' and 'persona' in Stoic anthropology. Some remarks on Cicero, De Officiis I" in D Kretzmer \& E Klein (eds) The Concept of Human Dignity in Human Rights Discourse (Den Haag): 105-107

Cancik, H (2005) 'Die frühesten antiken Texte zu den Begriffen 'Menschenrecht,' 'Religionsfreiheit,' 'Toleranz'” in KM Girardet \& U Nortmann (eds) Menschenrechte und Europäische Identität. Die Antiken Grundlagen (Stuttgart): 94-96

Coing, H (1982) “Zur Geschichte des Begriffs 'Subjektives Recht”' in Gesammelte Aufsätze zu Rechtsgeschichte, Rechtsphilosophie und Zivilrecht vol 1 (Frankfurt am Main): 253-258

Coenraad, L (2000) Het Beginsel van Hoor en Wederhoor in het Romeinse Procesrecht (Deventer)

Crifò, G (1976) "Ulpiano. Esperienze e responsabilità del giurista" in H Temporini (ed) Aufstieg und Niedergang der römischen Welt (Berlin, New York): 2-15

Dombrovski, DA (1987) "Porphyry and vegetarianism. A contemporary philosophical approach" in W Haase (ed) Aufstieg und Niedergang der römischen Welt vol 2262 (Berlin, New York): 774-791

Gaudemet, J (1995) “Des 'droits de l'homme' dans l'Antiquité?” in R Feenstra et al (eds) Collatio iuris Romani. Études dédiées à Hans Ankum à l'Occasion de Son 65me Anniversaire (Amsterdam): 105-114

Giltaij, J (2011) Mensenrechten in het Romeinse Recht? (Nijmegen)

Greenidge, AHJ (1894) Infamia: Its place in Roman Public and Private Law (Oxford)

Hagemann, M (1998) Iniuria. Von den XII Tafeln bis zur Justinianischen Kodifikation (Köln, Weimar, Wien)

Halme-Tuomisaari, M \& Slotte, P(eds) (2015) Revisiting the Origins of Human Rights (Cambridge) Honoré, T (2002) Ulpian: Pioneer of Human Rights (Oxford) 


\section{JACOB GILTAIJ}

Kaser, M (1956) “Infamia und ignominia in den römishen Rechtsquellen” Zeitschrift der SavignyStiftung für Rechtsgeschichte: Romanistische Abteilung 73: 220-278

Kunkel, W (1967) Herkunft und Soziale Stellung der Römischen Juristen (Graz, Wien, Köln)

Lenel, O (1887-1889) Palingenesia Juris Civilis vols 1 \& 2 (Leipzig)

Lenel, O (1956) Das Edictum Perpetuum. Ein Versuch zu seiner Wiederherstellung (Aalen)

Liebs, D (1966) "Review of Bonini, Libri de cognitionibus" Tijdschrift voor Rechtsgeschiedenis 34: $254-266$

Long, AA (1974) Hellenistic Philosophy. Stoics, Epicureans, Skeptics (London)

Long, AA \& Sedley, DN (1987a) The Hellenistic Philosophers vol 1 (tr of the principal sources with philosophical commentary) (Cambridge)

Long, AA \& Sedley, DN (1987b) The Hellenistic Philosophers vol 2 (Greek and Latin texts with notes and bibliography) (Cambridge)

Mommsen, T (1899) Römisches Strafrecht (Leipzig)

Moyn, S (2014) Human Rights and the Uses of History (London, New York)

Moyn, S (2015) Christian Human Rights (Philadelphia)

Nogrady, A (2006) Römisches Strafrecht nach Ulpian. Buch 7 bis 9 De Officio Proconsulis (Berlin)

Pessers, DWJM (2005) Menselijke Waardigheid en het Persoonsbegrip in het Recht (Utrecht)

Pohlenz, M (1992) Die Stoa. Geschichte einer Geistigen Bewegung vol 1 (Göttingen)

Reesor, ME (1951) "The 'indifferents' in the old and middle Stoa” Transactions and Proceedings of the American Philological Society 82: 102-110

Rist, JM (1969) Stoic Philosophy (Cambridge)

Rist, JM (1982) Human Value. A Study in Ancient Philosophical Ethics (Leiden)

Robinson, OF (2007) Penal Practice and Penal Theory in Ancient Rome (London, New York)

Schrage, EJH (1975) Libertas est Facultas Naturalis. Menselijke vrijheid in een Tekst van Florentinus (Leiden)

Smith, A (1987) "Porphyrian studies since 1913" in W Haase (ed) Aufstieg und Niedergang der römischen Welt vol 2362 (Berlin, New York): 717-773

Stagl, JF (2012) “Die Personwerdung des Menschen: Anfänge im Römischen Recht” in H Thomas \& J Hattler (eds) Personen- Zum Miteinander Einmaliger Freiheitswesen (Frankfurt am Main): 89-109

Van Beers, B (2009) Persoon en Lichaam in het Recht. Menselijke Waardigheid en Zelfbeschikking in het Tijdperk van de Medische Biotechnologie (Den Haag)

Von Lübtow, U (1948) "De iustitia et iure" Zeitschrift der Savigny-Stiftung für Rechtsgeschichte: Romanistische Abteilung 66: 458-565

Waider, H (1961) “'Ars iuris' und 'suum in persona ipsa' bei Hugo Donellus, Ein Beitrag zur Geschichte der Metholodologie und der Lehre von den Menschenrechten" Archiv für Geschichte der Philosophie 43: 52-69

Waldron, J (2012) Dignity, Rank and Rights (Oxford)

Wallis, RT (1972) Neoplatonism (London)

Weiss, R (2001) Virtue in the Cave (Oxford) 
Whitman, JQ (2003) “On Nazi 'honour' and the new European 'dignity”” in C Joerges \& N Singh Ghaleigh (eds) Darker Legacies of Law in Europe (Oxford, Portland): 243-266

Whitman, JQ (2004) “The two Western cultures of privacy: Dignity versus liberty” Yale LJ 113: 1151-1221

Yavetz, Z (1974) "Existimatio, fama and the ides of March" Proceedings of the Harvard Philological Society 78: 35-65 